\title{
Carbon Steel Slag as Cementitious Material for Self-Consolidating Concrete
}

\author{
Yu-Chu Peng \\ Graduate Institute of Construction Engineering, National Taiwan \\ University of Science and Technology, \\ Depart of Leisure Management, Taiwan Hospitality \& Tourism College,
}

China,Taiwan

\section{Introduction}

In Taiwan, self-consolidating concrete (SCC) exhibiting high-flow behaviour is a widely used concrete material to prevent conventional concrete problems such as honeycomb structures that occur as a result of poor practice. SCC is also used as the material of choice for heavily reinforced concrete structures located in seismic zones [Paczkowski Piotr,Kaszynska Maria,2007.]. Pozzolanic materials are important ingredients for making SCC [Mihashi H, Yan X,1995.]. For many years, pozzolanic admixtures, such as blast furnace slag (BFS), pulverized coal ash (fly ash), silica fumes, and copper slag have been recycled to partially replace Portland cement in concrete mixtures. The main advantages of using pozzolanic materials are improvements in performance and significant reduction in the life-cycle costs of concrete structures; the latter, in particular, continues as a significant problem for engineers [Khalifa AJ, Ramzi T,2002. Li G, Zhao X.,2003. Zhang MH, Bilodeau A, Malhotra VM, Kim KS, Kim JC,1999.]. Materials such as steel slag, normally considered as waste, have promising applications as partial Portland cement replacements in concrete mixtures. Considerable research and development has been conducted to develop new concrete technologies such as SCC. Further, the construction of durable concrete has also been pursued. Initially, pozzolanic admixtures were solid waste and it was extremely costly to treat and dump them into a final storage area. Today, however, in the concrete industries in Taiwan and elsewhere, these admixtures are important materials for the production of low-cost durable concrete, and an example of environmental protection and resource conservation.

In Taiwan, carbon steel slag (CSS) is a by-product of the reduction during the production of refining carbon steel in an arc furnace, and is seldom recycled. On average, the production of one ton of carbon steel yields $10 \mathrm{~kg}$ of CSS waste, and hence, in Taiwan, more than 56,000 tons of CSS is produced each year. Due to the relatively small amounts of CSS relative to blast furnace slag (BFS), environmental protection agency (EPA) regulations had previously permitted the dumping of CSS. Today, the dumping of such waste is not permitted, and the proper disposal of CSS has become a huge problem. Since lime, coke and silicon iron are added to promote the reducing process during high-temperature-refinery scrap steel procedures, the CSS contains large amounts of $\mathrm{CaO}, \mathrm{SiO}_{2}$ and $\mathrm{Al}_{2} \mathrm{O}_{3}$. This waste composition, however, is similar to BFS or Portland cement [Chiang CC, Chenn YY, Lin TY, 
Hwang CL,2004.Yu-Chu Peng,2009.]. Hence, CSS can be considered for use as a pozzolanic admixture to partially replace Portland cement in a concrete mixture.

Rather than use CSS for backfill soil or as material to be retained in the plant, steel slag can be regarded as a low-quality clinker and can be used to partially substitute the clinker of composite Portland cement [Wu X, Zhu H, Hou X, Li H,1999.Sakuraya T,1999.]. In Japan and other industrialized countries, steel slag has already been applied for use in civil engineering applications such as road base construction and soil stabilization [Geiser J.,1999. Roy DM, Idorn GM.,1982.]. In Germany, anbout $17.1 \%$ of steel slag is used for highway construction, $5.4 \%$ is recycled, and $40.5 \%$ is used in agricultural fertilizer production [Luxán MP, Sotolongo R, Dorrego F, Herrero E.2000. Monshi A, Asgarani MK,1999. Mihashi H, Yan X, Arikawa S.,1995. Hogan FJ, Meusel JW.,1981. ACI Committee 211.,1993.]. The mineralogical composition of steel slag is as follows: anhydrous calcium silicates and silicoaluminates; gehlenite, larnite and bredigite; magnetite and magnesioferrite and manganese oxides [Esfahani M. Reza,Kianoush M. Reza,2005. Hwang Soo-Duck,2008. Koehler Eric P. ,Fowler David W.,2008.]. Thus, some researchers have tested the effects of mixed iron slag $(36 \% \sim 45 \%)$, steel slag $(6 \% \sim 22 \%)$ and limestone $(40 \% \sim 64 \%)$ on the setting time of cement paste and the compressive strength at 3, 7 and 28 days [Schindler Anton K.,Barnes Robert W.,Roberts James B.,2007. Whitcomb Brent L., Kiousis Panos D.,2008.]. Nevertheless, other than documenting the chemical composition of CSS, there are few studies on the pozzolanic reactions after the addition of CSS.

\section{Research plan}

\subsection{Material}

The aggregate was quarried from I-Lan River, Northern Taiwan, and consisted of large amounts of elongate slate and fragile particles. The cement and superplasticizer (SP) used corresponded to ASTM C150 type I Portland cement and ASTM C494 type F high range water reducing agent (HWRA), respectively. A naphthalene lingo-sulfonate base was used for promoting the flow ability of SCC; the specific gravity was 1.18 ; ph, 6.93 and chloride ion content, less than $50 \mathrm{ppm}$. As a by-product of the carbon steel manufacturing process, while the carbon steel settles in the smelter (since its density is high), impurities remain on top. The carbon steel is then transported to a water basin maintained at a low temperature for solidification. The end product (CSS) is a hard solid material that is then sent to a crusher for further processing. The CSS is powdered to pass through sieve No. 4 (4.76 mm). Subsequently, it is re-ground for $3 \mathrm{~h}$ at a speed of $60 \mathrm{rpm}$ to pass through sieve No. 200 (75 $\mu \mathrm{m})$. In this study, type I Portland cement has been used. Class F fly ash and BF slag were obtained from Taiwan Power Company and China Steel Corporation, respectively. The SP was Glenium 51 obtained from Taiwan Durusle Company, Taiwan. In Table 1, the specific gravities of Portland cement and CSS are listed as 3.14 and 2.67, respectively; further, CSS powder and Portland cement (type I) have specific surface areas of $2504 \mathrm{~cm}^{2} / \mathrm{g}$ and 3622 $\mathrm{cm}^{2} / \mathrm{g}$, respectively. Hence, CSS has the least fineness, which is characteristic of materials with low surface areas. As shown in Table 2, CSS is highly alkaline, with a $\mathrm{pH}$ of 11.50, an absorption capacity (SSD) of $7.60 \%$, fineness modulus (FM) of 1.76 according to ASTM C136, and dry loose density of $1266 \mathrm{~kg} / \mathrm{m}^{3}$ according to ASTM C29. Figure 1 shows the relationships of CSS with BFS and Portland cement; the percentage of the main composition $\left(\mathrm{SiO}_{2}\right.$ and $\left.\mathrm{CaO}\right)$ of CSS lies between that of BFS and Portland cement. 


\begin{tabular}{|c|c|c|c|}
\hline & Item & $\mathrm{OPC}$ & CSS \\
\hline \multirow{6}{*}{ Physical properties } & Specific gravity & 3.14 & 2.67 \\
\hline & Specific surface area $\left(\mathrm{cm}^{2} / \mathrm{g}\right)$ & 3622 & 2504 \\
\hline & $\mathrm{pH}$ & - & 11.50 \\
\hline & Absorption capacity (\%) & - & 7.60 \\
\hline & Fineness modulus (FM) & - & 1.76 \\
\hline & Dry loose density $\left(\mathrm{kg} / \mathrm{m}^{3}\right)$ & - & 1266 \\
\hline \multirow{10}{*}{$\begin{array}{l}\text { Chemical compositions } \\
\qquad(\%)\end{array}$} & $\mathrm{SiO}_{2}$ & 21.46 & 26.52 \\
\hline & $\mathrm{Al}_{2} \mathrm{O}_{3}$ & 4.84 & 5.95 \\
\hline & $\mathrm{Fe}_{2} \mathrm{O}_{3}$ & 3.12 & 3.78 \\
\hline & $\mathrm{CaO}$ & 62.34 & 46.45 \\
\hline & $\mathrm{MgO}$ & 2.87 & 13.27 \\
\hline & $\mathrm{SO}_{3}$ & 2.06 & 0.65 \\
\hline & $\mathrm{f}-\mathrm{CaO}$ & 0.88 & 2.11 \\
\hline & $\mathrm{Na}_{2} \mathrm{O}$ & 0.22 & 0.26 \\
\hline & $\underline{\mathrm{K}_{2} \mathrm{O}}$ & 0.70 & 0.11 \\
\hline & $\overline{\mathrm{CaO} / \mathrm{SiO}_{2}}$ & 2.91 & 1.75 \\
\hline
\end{tabular}

Table 1. Physical properties and chemical composition of OPC and CSS.

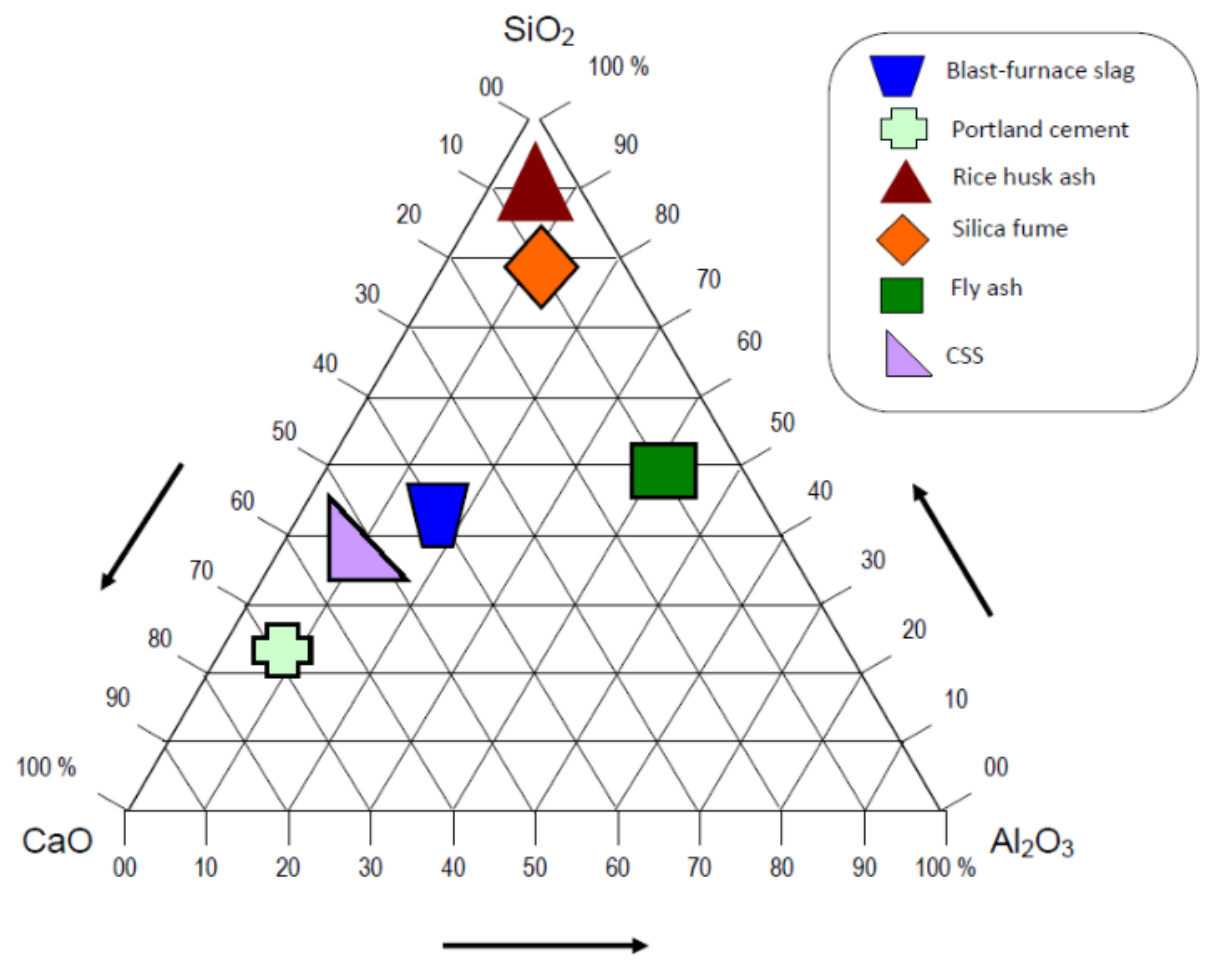

Fig. 1. Comparison of compositions of CSS, BFS and Portland cement. 


\subsection{Mixture design}

In order to obtain high-strength SCC with lower water content $\left(160 \mathrm{~kg} / \mathrm{m}^{3}\right)$, in this study, $\mathrm{w} / \mathrm{cm}$ ratios (water/(cement $+\mathrm{CSS}$ )) of $0.28,0.32$ and 0.40 were selected. Further, large amounts of SP were added to achieve better flow behaviour. CSS powder was used to replace the $5.0 \%, 7.5 \%$ and $10 \%$ weights of Portland cement. Mixtures with three different $\mathrm{w} / \mathrm{cm}$ ratios were prepared for ordinary plain concrete (OPC) and carbon steel slag concrete (CSC), as shown in Table 2; designated as OPC28, OPC32 and OPC40 and CSC28, CSC32 and CSC40, respectively [Whitcomb Brent L., Kiousis Panos D.,2009. Kwan Albert K. H.,Ng, Ivan Y. T.,2008. ] .

\begin{tabular}{ccccccccccc}
\hline & & \multicolumn{7}{c}{ Mix Proportion $\left(\mathrm{kg} / \mathrm{m}^{3}\right)$} \\
\cline { 5 - 11 } $\begin{array}{c}\text { Designation } \\
\text { of concrete }\end{array}$ & $\begin{array}{c}\mathrm{w} / \mathrm{c} \\
\text { ratio }\end{array}$ & $\begin{array}{c}\mathrm{w} / \mathrm{cm} \\
\text { ratio }^{\mathrm{b}}\end{array}$ & $\begin{array}{c}\text { CSS/ } \\
\text { Cement }\end{array}$ & $\begin{array}{c}\text { cement } \\
(\%)\end{array}$ & $\begin{array}{c}\text { Fine } \\
\text { aggregate }\end{array}$ & $\begin{array}{c}\text { Coarse } \\
\text { aggregate }\end{array}$ & Water SPc & $\begin{array}{c}\text { Water } \\
+ \text { SP }\end{array}$ \\
\hline OPC28 & 0.28 & 0.28 & 572 & -- & 757 & 901 & 145 & 15 & 160 \\
OPC32 & 0.32 & 0.32 & 500 & -- & 783 & 932 & 148 & 12 & 160 \\
OPC40 & 0.40 & 0.40 & 400 & -- & 820 & 976 & 152 & 8 & 160 \\
CSC28 & 0.28 & 0.28 & 545 & 5.0 & 832 & 820 & 146 & 14 & 160 \\
CSC32 & 0.34 & 0.32 & 465 & 7.7 & 861 & 849 & 149 & 11 & 160 \\
CSC40 & 0.44 & 0.40 & 364 & 10.0 & 901 & 888 & 153 & 7 & 160 \\
\hline
\end{tabular}

$\mathrm{a} \mathrm{w} / \mathrm{c}$ ratio $=$ water $/$ cement

${ }^{\mathrm{b}} \mathrm{w} / \mathrm{cm}$ ratio $=$ water $/($ cement + CSS)

c SP = Superplasticizer

Table 2. Mixture proportion of SCC.

\section{Results and discussions}

\subsection{Workability of SCC}

Figure 2 illustrates slump vs. different $\mathrm{w} / \mathrm{cm}$ ratios for both OPC and CSC; the figure indicates that all slump values are greater than $230 \mathrm{~mm}$, the specification for SCC with high flow. Concrete with a lower $\mathrm{w} / \mathrm{cm}$ ratio than 0.28 -implying significantly high binder content-may lead to higher slump and satisfactory flowability. For an identical dosage of SP mixtures, CSC has higher slump than OPC mixtures. Hence, it is clear that the use of CSS might improve the workability of SCC; and this is similar to the test results of the research papers referenced. Hence, the use of CSS in SCC can lead to high flow properties.

\subsection{Setting time of SCC}

Figure 3 shows the effects of CSS on the penetration resistance of concrete, indicating that as the $\mathrm{w} / \mathrm{cm}$ ratio of OPC or CSC increases, the penetration resistance decreases and the setting time increases. Further, the setting time of CSC is longer than that of OPC irrespective of the $\mathrm{w} / \mathrm{cm}$ ratio. This is due to the low PAI values of CSS. Thus, the setting time increases with the amount of CSS. This result is similar to the results in a previous study, which showed that the addition of BFS decreased the setting time of SCC [Mihashi H, Yan X, Arikawa S.,1995.]. 


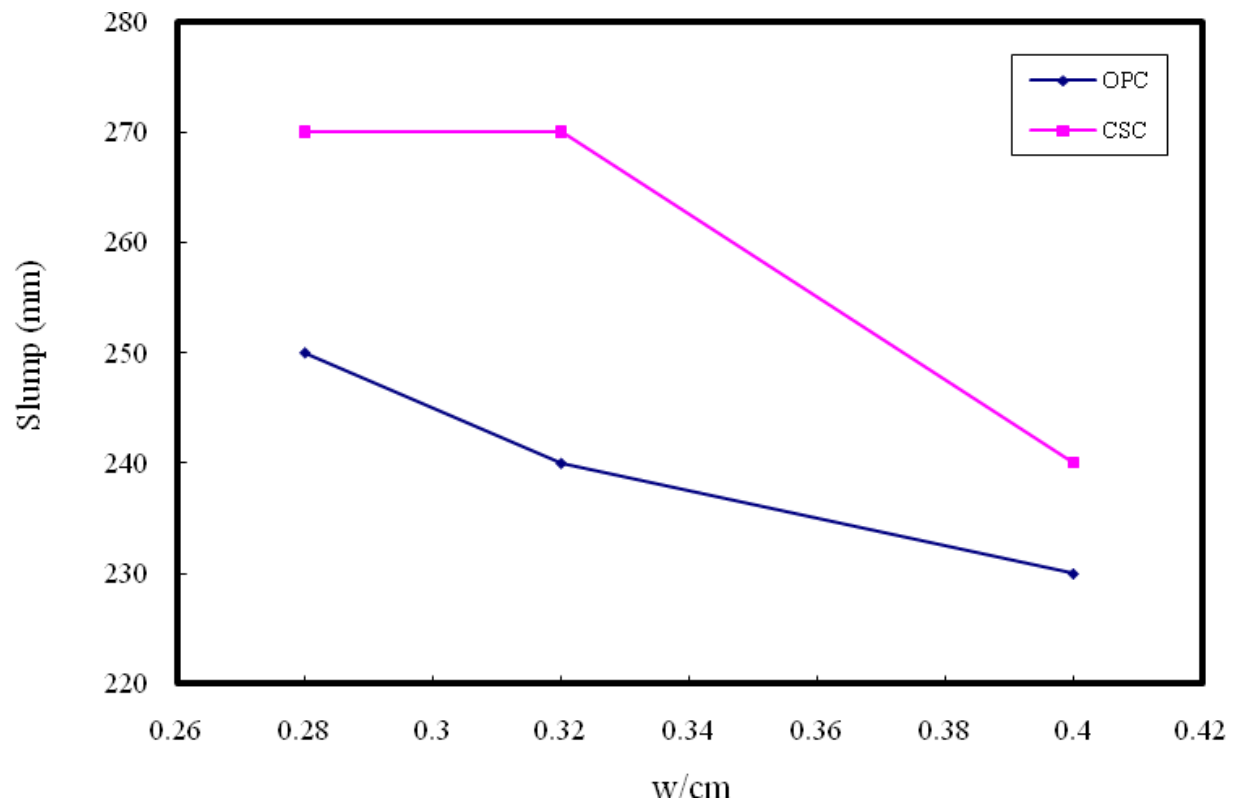

Fig. 2. Slump vs. various $\mathrm{w} / \mathrm{cm}$ ratios of concrete.

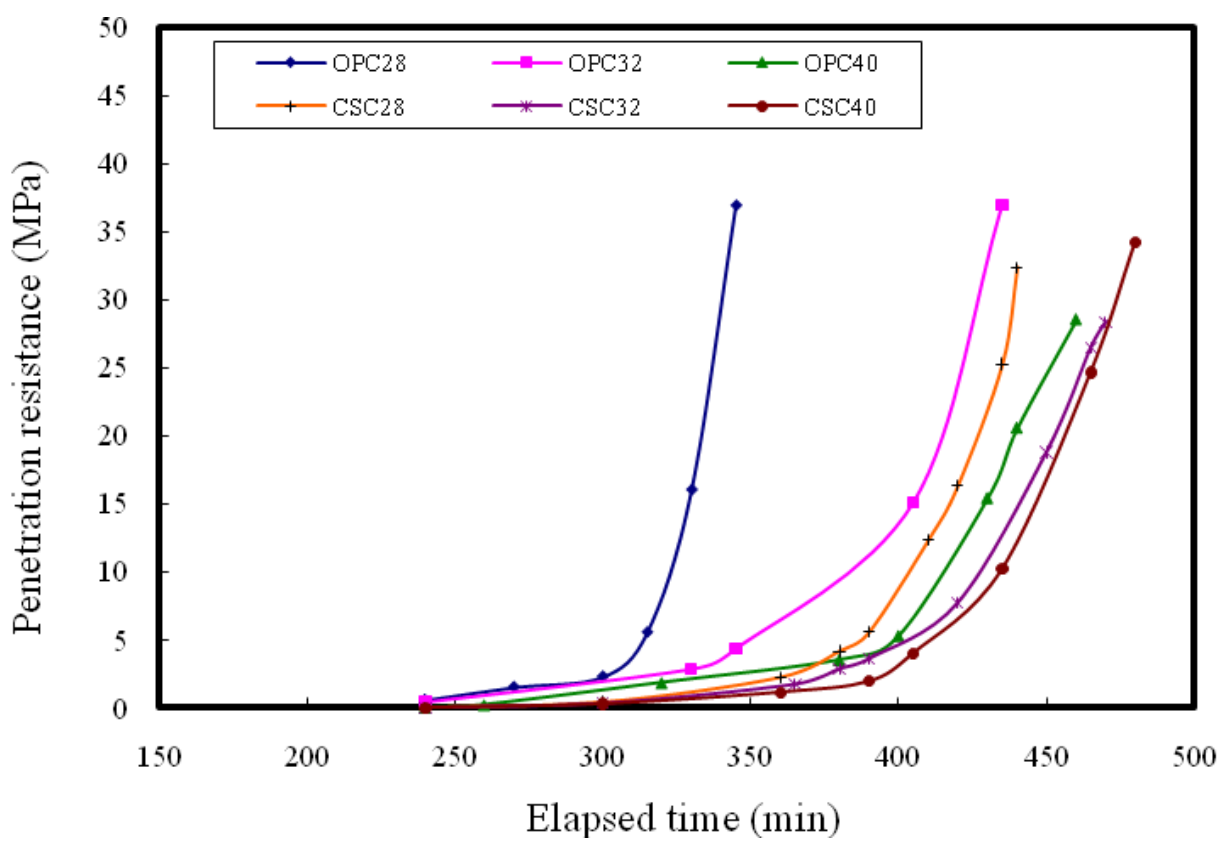

Fig. 3. Comparison between the OPC and CSC with respect to penetration resistance of concrete. 


\subsection{Compressive strength of SCC}

The compressive strength and percentage of concrete mixtures with different $\mathrm{w} / \mathrm{cm}$ values at the specified age are shown in Table 3. The compressive strength of each mixture is greater than $41 \mathrm{MPa}$ at 56 days. This satisfies the requirement that SCC must have high strength [Hogan FJ, Meusel JW.,1981.]. The compressive strength of OPC and CSC with a $\mathrm{w} / \mathrm{cm}$ ratio of 0.28 is either equal to or higher than $83 \mathrm{MPa}$ at 90 days; however, that of CSC28 at any age is lower than that of OPC28. In contrast, the percentage of compressive strength is higher than $90 \%$ at 28 days, and it is reduced to $76 \%$ at 90 days. This corresponds to a $15 \%$ reduction in the PAI at 28 days. The compressive strength of CSC with a w/cm ratio of 0.32 or 0.40 at any age, however, is higher than that of OPC, and the percentages of compressive strength are from $106 \%$ to $134 \%$ and from $108 \%$ to $121 \%$, with respect to the $\mathrm{w} / \mathrm{cm}$ ratio. This clearly indicates that the addition of CSS improves the strength development of cement paste as long as the water-to cement $(\mathrm{w} / \mathrm{c})$ ratio is greater than 0.32 or $\mathrm{w} / \mathrm{cm}$ is higher than 0.28 . This means that the reactions of strength development of cement with CSS will be enhanced with sufficient water contents. It is suggested, however, that the total water content of concrete, including the moisture in liquid admixture be maintained as low as possible to avoid large shrinkage and sedimentation. Figure 4 shows the influence of CSS content on compressive strength: higher CSS content mixtures will cause lower compressive strength.

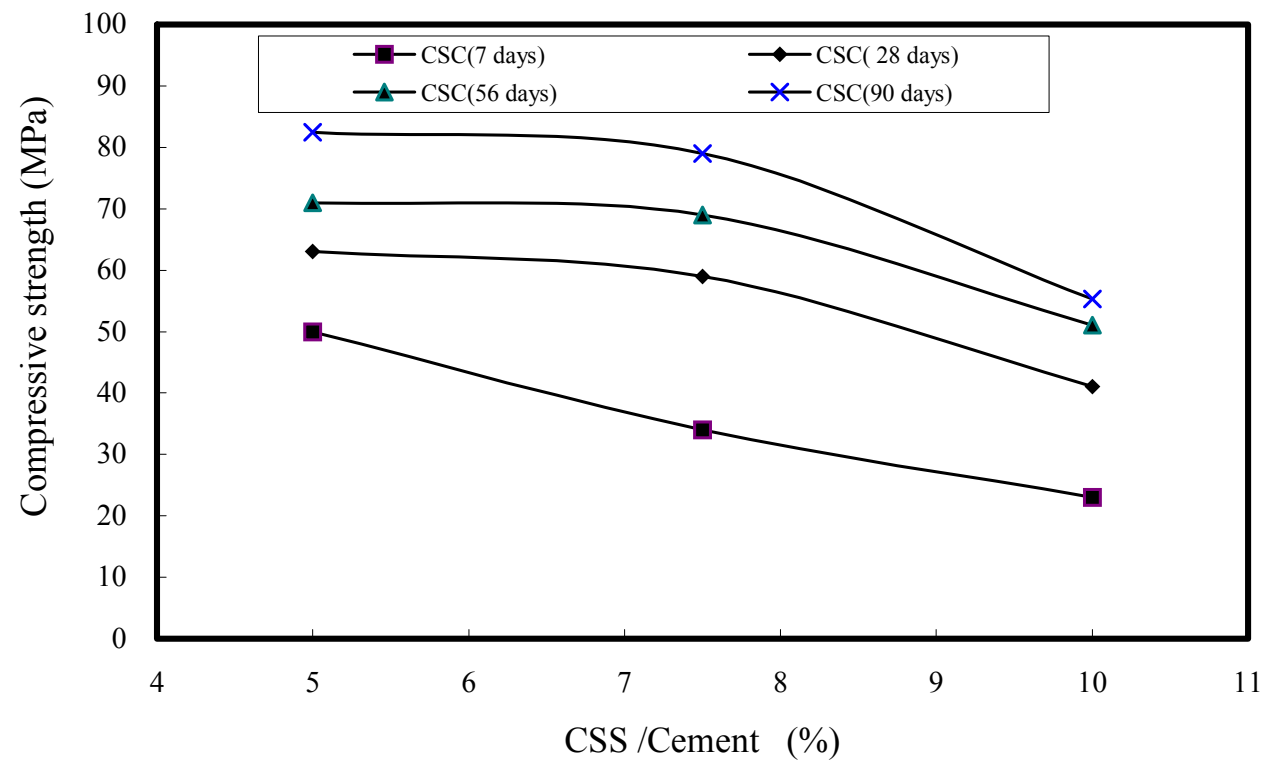

Fig. 4. Effect of CSS content at different ages on the compressive strength of SCC. 


\begin{tabular}{llllllll}
\hline \multirow{2}{*}{$\begin{array}{l}\text { Designation } \\
\text { of concrete }\end{array}$} & $\begin{array}{l}\text { w/c } \\
\text { ratio }\end{array}$ & $\begin{array}{l}\text { w/cm } \\
\text { ratio }\end{array}$ & \multicolumn{6}{l}{ Compressive strength, MPa (\% compressive strengtha) } \\
\cline { 5 - 8 } & & & 3 days & 7 days & 28 days & 56 days & 90 days \\
\hline OPC28 & 0.28 & & $46.5(100)$ & $53.9(100)$ & $69.6(100)$ & $93.7(100)$ & $95.6(100)$ \\
CSC28 & 0.29 & & $42.9(92)$ & $50.0(93)$ & $63.2(91)$ & $71.0(76)$ & $82.5(86)$ \\
OPC32 & 0.32 & & $25.0(100)$ & $32.0(100)$ & $49.6(100)$ & $57.3(100)$ & $59.1(100)$ \\
CSC32 & 0.34 & & $26.5(106)$ & $34.1(107)$ & $58.5(118)$ & $69.4(121)$ & $78.9(134)$ \\
OPC40 & 0.40 & & $16.3(100)$ & $22.2(100)$ & $37.1(100)$ & $45.1(100)$ & $45.8(100)$ \\
CSC40 & 0.44 & & $17.6(108)$ & $24.1(109)$ & $40.7(110)$ & $50.6(112)$ & $55.3(121)$ \\
\hline
\end{tabular}

Table 3. Compressive strength and percentage compressive strength of concrete.

\subsection{Ultrasonic pulse velocity (UPV) of SCC}

Theoretically, the ultrasonic pulse velocity (UPV) of a solid object is higher that of air, and a high-density solid will have high UPV. Therefore, the UPV is a good measure of the soundness of hardened concrete. It is generally acknowledged that the UPV increases with concrete density. In our study, the UPV of all mixtures was greater than $4200 \mathrm{~m} / \mathrm{s}$. Table 4 shows the UPV and the difference in UPV between CSC and OPC (as a percentage) at each $\mathrm{w} / \mathrm{cm}$ ratio, from 3 to 90 days. The UPV of CSC28 at all ages is lower by $1 \%$ to $2 \%$ than that of OPC28; however, the UPV of CSC32 and CSC40 is higher by 3\% than that of OPC32 and OPC40, respectively. This result is similar to trend in compressive strength - the addition of CSS enhances the pozzolanic reaction with high $\mathrm{w} / \mathrm{c}$ or $\mathrm{w} / \mathrm{cm}$ ratios, i.e., sufficient water. Figure 5 shows a good linear relationship between the compressive strength and UPV of concrete for both OPC and CSC. In other words, UPV is a good method for evaluating the performance and homogeneity of SCC.

\begin{tabular}{cccccccc}
\hline \multirow{2}{*}{$\begin{array}{c}\text { Designation } \\
\text { of concrete }\end{array}$} & \multirow{2}{*}{$\begin{array}{c}\mathrm{w} / \mathrm{c} \\
\text { ratio }\end{array}$} & $\mathrm{w} / \mathrm{cm}$ & \multicolumn{5}{c}{ UPV of concrete, $\mathrm{m} / \mathrm{s}(\%$ UPVa $)$} \\
\cline { 5 - 8 } & & & 3 days & 7 days & 28 days & 56 days & 90 days \\
\hline OPC28 & 0.28 & & $4606(100)$ & $4787(100)$ & $4859(100)$ & $4876(100)$ & $4890(100)$ \\
CSC28 & 0.29 & 0.28 & $4525(98)$ & $4683(98)$ & $4828(99)$ & $4830(99)$ & $4835(99)$ \\
OPC32 & 0.32 & & $4381(100)$ & $4523(100)$ & $4760(100)$ & $4777(100)$ & $4785(100)$ \\
CSC32 & 0.34 & 0.32 & $4466(102)$ & $4669(103)$ & $4814(101)$ & $4821(101)$ & $4825(101)$ \\
OPC40 & 0.40 & & $4211(100)$ & $4274(100)$ & $4595(100)$ & $4635(100)$ & $4651(100)$ \\
CSC40 & 0.44 & 0.40 & $4295(102)$ & $4361(102)$ & $4659(101)$ & $4709(102)$ & $4728(102)$ \\
\hline
\end{tabular}

a Percentage UPV $=(\mathrm{CSC} / \mathrm{OPC}) \times 100$ at fixed $\mathrm{w} / \mathrm{cm}$ ratios

Table 4. UPV and percentage UPV of SCC. 


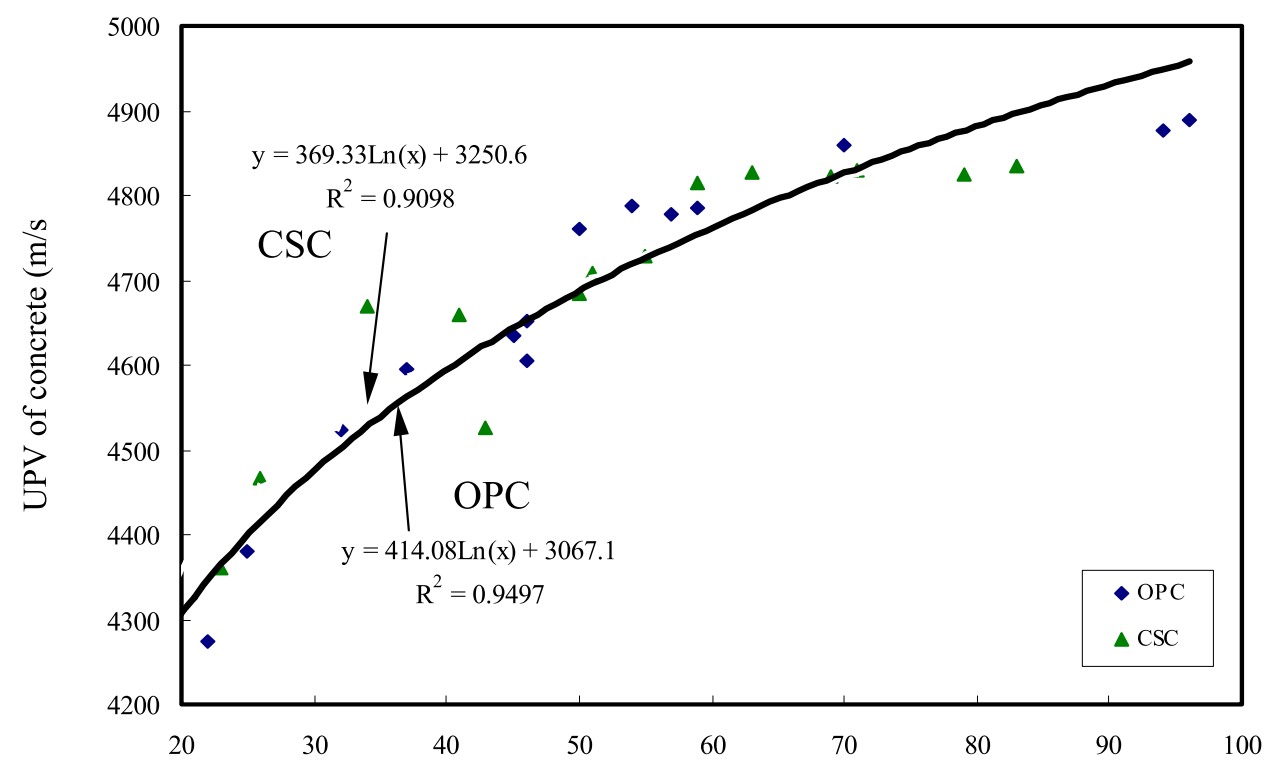

Compressive strength (MPa)

Fig. 5. Relationship between UPV and compressive strength of OPC and CSC.

\subsection{Microstructure observation}

Scanning electron microscopy (SEM) observations are conducted with specimens at the ages of 3 and 28 days. The image characteristics of concrete at 3 days are shown in Figs. 6(a)-8(a). As shown in Fig. 6(a), at the early age of 3 days, considerable amounts of hexagonal-shaped calcium hydroxide $\left(\mathrm{Ca}(\mathrm{OH})_{2}\right)$, spherical-shaped C-S-H gel in CSC28 $(\mathrm{w} / \mathrm{cm}=0.28)$ and certain amounts of fine pores (dark zone) exist. Figure $7(\mathrm{a})$ shows the presence of numerous rosette-shaped mono-sulfoaluminate (AFm) and small amounts of needle-shaped ettringite $(\mathrm{AFt})$ in CSC32 $(\mathrm{w} / \mathrm{cm}=0.32)$. Figure $8(\mathrm{a})$ also shows that there are rosette-shaped AFm in CSC40 $(\mathrm{w} / \mathrm{cm}=0.40)$. Here, the $\mathrm{w} / \mathrm{cm}$ ratio is greater than or equal to 0.32 as a result of increase in CSS amounts and the existence of high $\mathrm{Al}_{2} \mathrm{O}_{3}$ and $\mathrm{Fe}_{2} \mathrm{O}_{3}$ contents. The primary hydration products are hexagonal-shaped $\mathrm{Ca}(\mathrm{OH})_{2}$, spherical-shaped C-S-H gel and a certain amount of rosette-shaped AFm. This observation confirms the conclusions made for both strength and UPV that the reaction of CSS with cement paste requires sufficient water to aid hydration. At a later age, as shown in Fig. $6(\mathrm{~b})$, the microstructure of CSC28 is extremely dense. Figure 7(b) also shows the presence of numerous rosette-shaped AFm, but no needle-shaped Aft, while Fig. 8(b) shows large pores in CSC40 with a large amount of hexagonal-shaped $\mathrm{Ca}(\mathrm{OH})_{2}$ in the reaction process. While this is advantageous for the hydration reaction of CSS, it also indicates that more pores are observed with higher $\mathrm{w} / \mathrm{cm}$ ratios. 


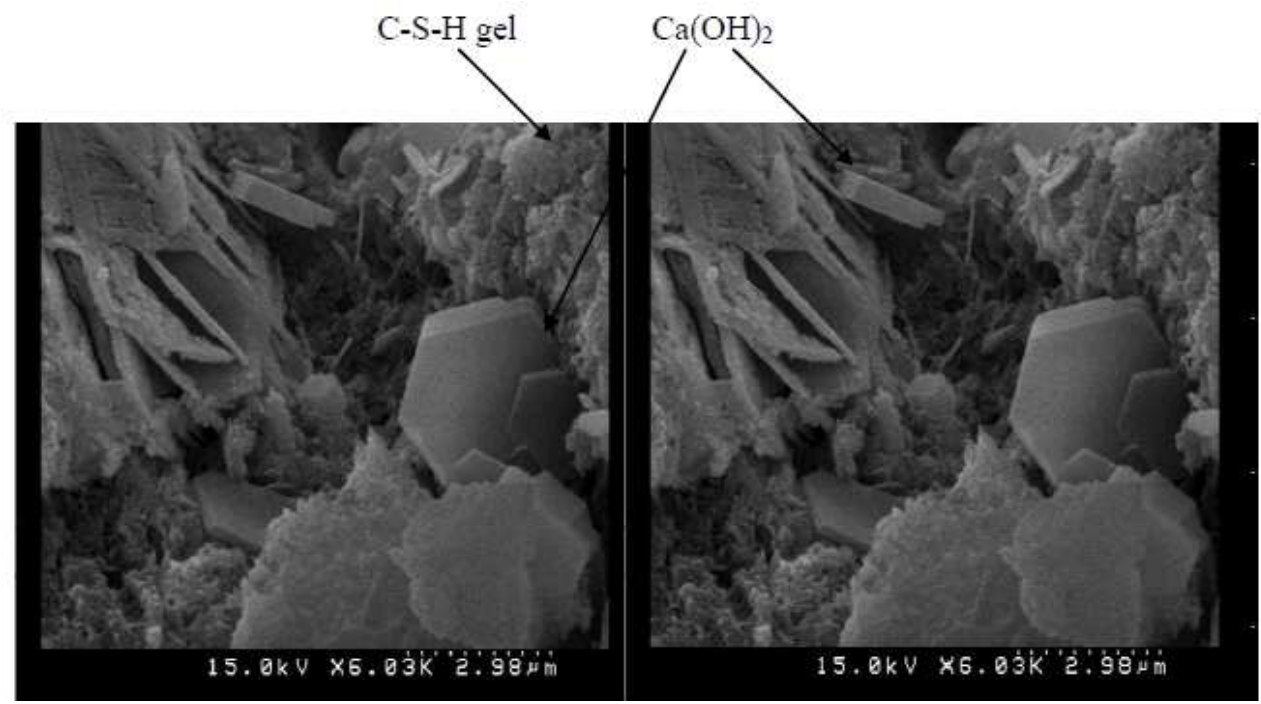

(a)

(b)

Fig. 6. SEM micrograph of CSC28: (a) at 3 days; (b) at 28 days.

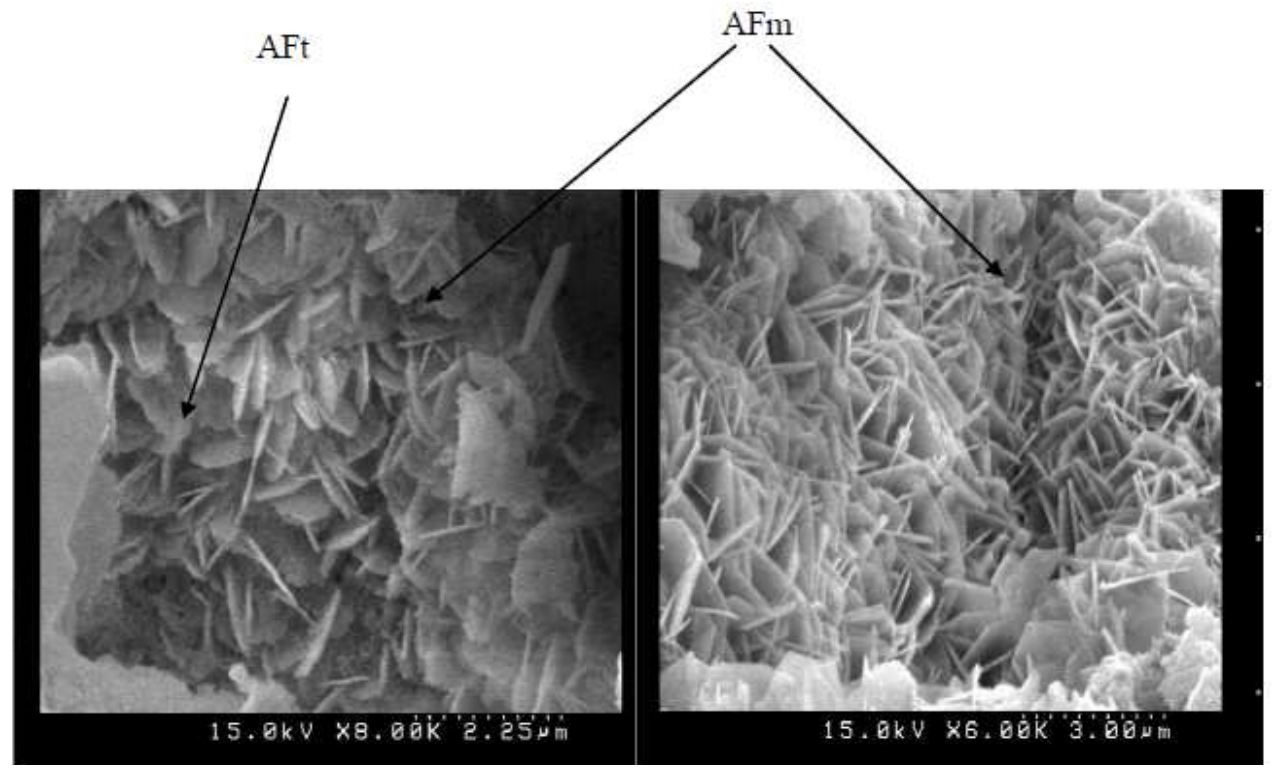

(a)

(b)

Fig. 7. SEM micrograph of CSC32: (a) at 3 days; (b) at 28 days. 


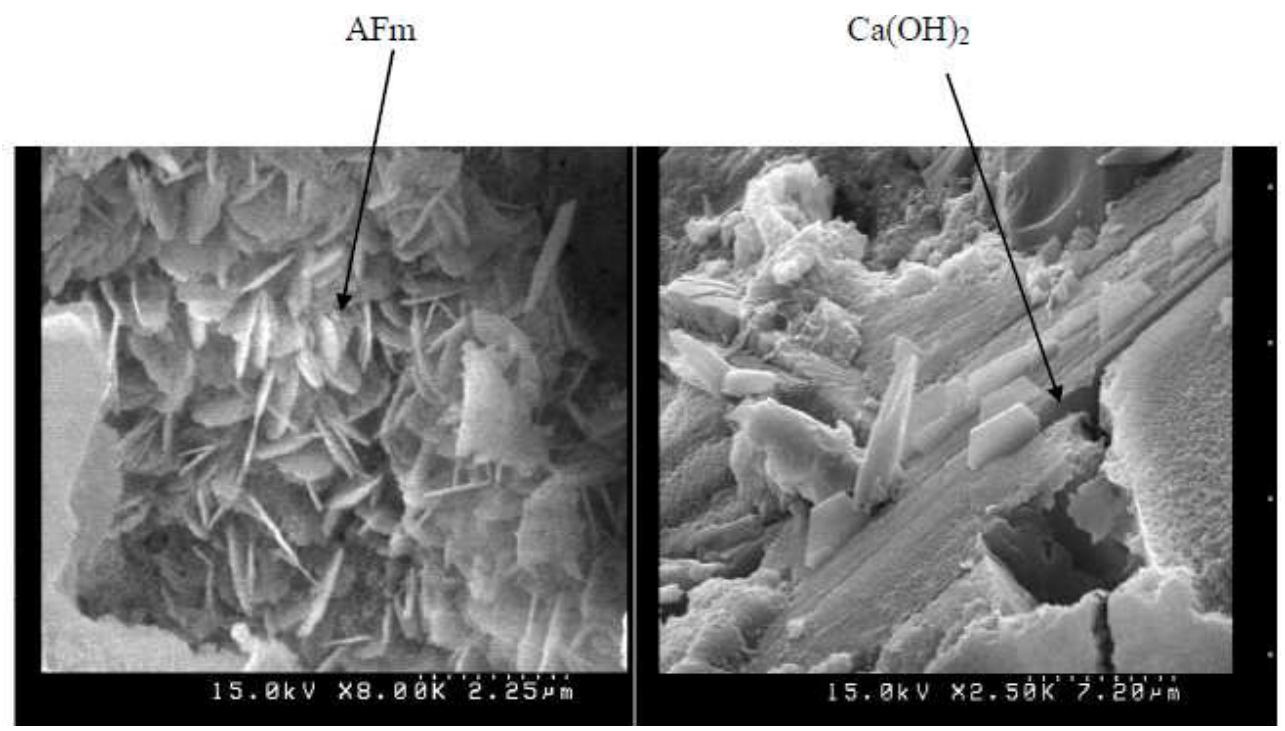

(a)

(b)

Fig. 8. SEM micrograph of CSC32: (a) at 3 days; (b) at 28 days.

\section{Conclusions}

In this study, we have conducted investigations on the recycling of carbon steel slag CSS to produce SCC. Our conclusions are as follows:

- The major chemical compositions of $\mathrm{CSS}$ are $\mathrm{CaO}, \mathrm{Al}_{2} \mathrm{O}_{3}$ and $\mathrm{SiO}_{2}$, a composition similar to that of Portland cement and BFS. The PAI of CSS is $85 \%$ at 28 days. Hence, CSS can be expected to have good cementitious properties and effects.

- CSS can be designed as easily as SCC. In comparison with OPC, increasing the CSS content will increase the setting time.

- Concrete using CSS has a higher compressive strength than that using OPC. If $\mathrm{w} / \mathrm{cm}$ ratios of 0.32 or 0.40 are used, the percentage of compressive strength increases by more than $21 \%$ at 90 days.

- As the amount of CSS in concrete increases, the compressive strength decreases. The strength is similar to other concrete, however, when CSS of $5.0-7.5 \%$ is used, except at 7 days.

- The SEM images show that the hydration rate of CSS is lower than that of OPC. Further, large amounts of $\mathrm{Ca}(\mathrm{OH})_{2}$ and AFm are present in CSS as a cementitious material.

In this manner, we have shown that CSS can potentially be used as a cementitious material in self-consolidating concrete. 


\section{References}

[1] ACI Committee 211. Guide for selecting proportions for high-strength concrete. ACI Mater J 1993;90:272-283.

[2] Chiang CC, Chenn YY, Lin TY, Hwang CL. The application of electric arc furnace reduction slags to high performance concrete. Journal of the Chinese Institute of Civil and Hydraulic Engineering 2004;16:167-178.

[3] Esfahani M. Reza, Kianoush M. Reza, Bond strength of glass fibre reinforced polymer reinforcing bars in normal and self-consolidating concrete, Canadian Journal of Civil Engineering, v 32, n 3, p 553-560, June 2005.

[4] Gregori Amedeo, Ferron Raissa, Sun Zhihui, Shah Surendra, Experimental simulation of self-consolidating concrete formwork pressure, ACI Materials Journal, v 105, n 1, p 97-104, January/February 2008.

[5] Geiser J. Metallurgical slag-create a future construction material. The International Associate of Metallurgical Slag Recycle and Utilization. Beijing, 1999. p. 1-8.

[6] Hogan FJ, Meusel JW. Evaluation for durability and strength development of a ground granulated blast furnace slag. Cem Concr Aggregates 1981;3:40-52.

[7] Hwang Soo-Duck, Khayat Kamal H., Effect of mixture composition on restrained shrinkage cracking of self-consolidating concrete used in repair, ACI Materials Journal, v 105, n 5, p 499-509, September/October 2008.

[8] Koehler Eric P., Fowler David W., Dust-of-fracture aggregate microfines in selfconsolidating concrete, ACI Materials Journal, v 105, n 2, p 165-173, March/April 2008.

[9] Kwan Albert K. H., Ng, Ivan Y. T., Performance criteria for self-consolidating concrete, Transactions Hong Kong Institution of Engineers, v 15, n 2, p 35-41, June 2008.

[10] Khalifa AJ, Ramzi T, Mohammed AG. Use of Copper slag and cement by-pass dust as cementitious materials. Cem Concr Aggregates 2002;24:7-12.

[11] Luxán MP, Sotolongo R, Dorrego F, Herrero E. Characteristics of the slags produced in the fusion of scrap steel by electric arc furnace. Cem Concr Res 2000;30:517-519.

[12] Li G, Zhao X. Properties of concrete incorporating fly ash and ground granulated blastfurnace slag. Cem Concr Compos 2003;25:293-299.

[13] Mihashi H, Yan X, Arikawa S. Strength properties and frost damage resistance of high performance concrete using blast furnace slag and silica fume. In: Schwesinger P, editor. Proceedings of the Fourth Weimar Workshop on High Performance Concrete. Germany, 1995. p. 195-204.

[14] Monshi A, Asgarani MK. Producing Portland cement from iron and steel slag and limestone. Cem Concr Res 1999;29:1373-1377.

[15] Mihashi H, Yan X, Arikawa S. Strength properties and frost damage resistance of high performance concrete using blast furnace slag and silica fume. High Performance Concrete: Material Properties and Design. Germany, 1995. p. 195-204.

[16] Paczkowski Piotr, Kaszynska Maria, Self-consolidating concrete for on-site bridge applications, International Conference organised by the Institution of Civil Engineers, ICE, p 312-320, 2007. 
[17] PENG Yu-chu, HUANG Chau-long. Engineering properties of sintered waste sludge as lightweight aggregate in a densified concrete mixture [J]. J Chongqing Univ: Eng Ed [ISSN 1671-8224], 2009, 8(4): 231-238.

[18] Roy DM, Idorn GM. Hydration, structures, and properties of blast furnace slag cements, mortars, and concrete. ACI J 1982;82:444-457.

[19] Schindler Anton K., Barnes Robert W., Roberts James B., Rodriguez Sergio, Properties of self-consolidating concrete for prestressed members, ACI Materials Journal, v 104, n 1, p 53-61, January/February 2007.

[20] Sakuraya T. The utilizing condition of metallurgical slag and steel slag for Japanese Refinery Steel Industry. The International Associate of Metallurgical Slag Recycle and Utilization, Beijing, 1999. p. 15-20.

[21] Wu X, Zhu H, Hou X, Li H. Study on steel slag and fly ash composite Portland cement. Cem Concr Res 1999;29:1103-1106.

[22] Whitcomb Brent L., Kiousis Panos D., Development of self-consolidating concrete for thin wall applications including validation, Journal of Materials in Civil Engineering, v 21, n 10, p 587-593, 2009.

[23] Zhang MH, Bilodeau A, Malhotra VM, Kim KS, Kim JC. Concrete incorporating supplementary cementing materials: effect on compressive strength and resistance to chloride-ion penetration. ACI Mater J 1999;96:181-189. 


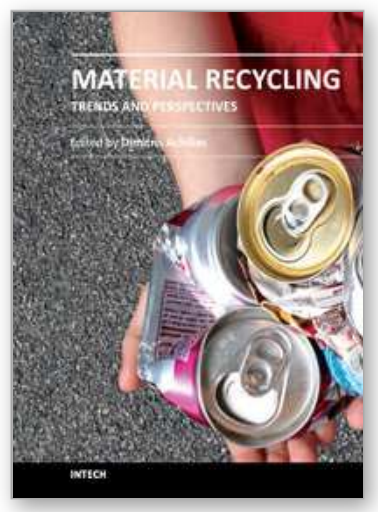

\author{
Material Recycling - Trends and Perspectives \\ Edited by Dr. Dimitris Achilias
}

ISBN 978-953-51-0327-1

Hard cover, 406 pages

Publisher InTech

Published online 16, March, 2012

Published in print edition March, 2012

The presently common practice of wastes' land-filling is undesirable due to legislation pressures, rising costs and the poor biodegradability of commonly used materials. Therefore, recycling seems to be the best solution. The purpose of this book is to present the state-of-the-art for the recycling methods of several materials, as well as to propose potential uses of the recycled products. It targets professionals, recycling companies, researchers, academics and graduate students in the fields of waste management and polymer recycling in addition to chemical engineering, mechanical engineering, chemistry and physics. This book comprises 16 chapters covering areas such as, polymer recycling using chemical, thermo-chemical (pyrolysis) or mechanical methods, recycling of waste tires, pharmaceutical packaging and hardwood kraft pulp and potential uses of recycled wastes.

\title{
How to reference
}

In order to correctly reference this scholarly work, feel free to copy and paste the following:

Yu-Chu Peng (2012). Carbon Steel Slag as Cementitious Material for Self-Consolidating Concrete, Material Recycling - Trends and Perspectives, Dr. Dimitris Achilias (Ed.), ISBN: 978-953-51-0327-1, InTech, Available from: http://www.intechopen.com/books/material-recycling-trends-and-perspectives/carbon-steel-slag-ascementitious-material-for-self-consolidating-concrete

\section{INTECH}

open science | open minds

\author{
InTech Europe \\ University Campus STeP Ri \\ Slavka Krautzeka 83/A \\ 51000 Rijeka, Croatia \\ Phone: +385 (51) 770447 \\ Fax: +385 (51) 686166 \\ www.intechopen.com
}

\author{
InTech China \\ Unit 405, Office Block, Hotel Equatorial Shanghai \\ No.65, Yan An Road (West), Shanghai, 200040, China \\ 中国上海市延安西路 65 号上海国际贵都大饭店办公楼 405 单元 \\ Phone: +86-21-62489820 \\ Fax: +86-21-62489821
}


(C) 2012 The Author(s). Licensee IntechOpen. This is an open access article distributed under the terms of the Creative Commons Attribution 3.0 License, which permits unrestricted use, distribution, and reproduction in any medium, provided the original work is properly cited. 